doi: 10.17492/pragati.v3i2.7743

\title{
An Analysis of Eco System of Indian Start-ups and Post Start-up Scenario of Selected Companies
}

\author{
Amit Kumar Singh*, Arun Kumar Attree** and Rohit Kumar Shrivastav ***
}

\begin{abstract}
This paper analyses the Indian experience of start-ups and the challenges face by the start-ups in India in terms of financial resources. India ranks third among global startup ecosystems with more than 4,200 new-age companies and it is amongst the top five countries in the world in terms of the new business start-ups. Many initiatives have been taken by the government to promote the environment of entrepreneurship and give incentives to young start-ups by providing the new and innovative schemes. These have not only provided funds to these start-ups but have also helped them in setting business with the help of information technology. The analysis of post start-up scenario of some selected companies highlights that when start-ups get the grip on the market, they are normally acquired by global companies, who normally retain the basic theme of the start-up. While India has seen an unprecedented growth in start-ups, there are some issues which India needs to resolve in order to promote and sustain its ecosystem of entrepreneurship and start-ups.
\end{abstract}

Keywords: Start-ups, Funding of start-ups, Entrepreneurship, India.

\subsection{Introduction}

A start-up is basically a young enterprise that has just started to develop with some innovative idea. With the technological advancement and increase in the growth rate and development of financial markets, the rate of growth of start-up have also increased manifold during the last decade. India is the $7^{\text {th }}$ largest country by the area size and also the $2^{\text {nd }}$ most populous country accommodating people over 1.2 billion.

*Associate Professor, Department of Commerce, Delhi School of Economics, University of Delhi (e-mail: amitipo10@gmail.com)

**Assistant Professor, Department of Commerce, Shaheed Bhagat Singh College, University of Delhi (e-mail: arunattree@gmail.com)

***Ph. D Research Scholar, Department of Commerce, University of Delhi (e-mail: rohitkshrivastav@gmail.com) 
The large population implies large potential market in India; but, it also leads to the heavy employment pressure in Indian economy. In the last couple of years, the selfemployment consciousness among the employment seeking persons, or in other words college students have increased and they are less likely to rely on their parents or college placement for getting the employment opportunities. Instead, they are taking the initiative to explore the new opportunities for themselves. As a result, start-ups are born. When a start-up gets the grip on the market and succeeds, it has been observed that sooner or later those start-ups get acquired by one of the leading companies in the same industry. The act of swallowing the start-up does not only reduce the new innovation but also loses its own working style. This paper aims to analyse the current situation of startups in India and the ultimate fate of these start-ups, when they get the grip on the market, being acquired by one of the leading company of similar industry.

The economy of an "entrepreneurial society" (Drucker, 1985) will be characterized by a high state of development; the US ${ }^{1}$ has had such an economy since the 1970s and Taiwan since the 1980s. In the last couple of years, India too, has seen the growth in the entrepreneurial society. The self-employment consciousness has been increased not only in the employment seeking persons but also in the young college going students too. There have been many cases where the person left the job to pursue a start-up rather doing a job even if the person was earning a handsome salary. This has given our entrepreneurial society a new opportunity to explore more dimensions of entrepreneurship with start-ups.

\subsection{Start-up: Conceptual Framework}

Start-up is an entity registered or incorporated in India not prior to 5 years having annual turnover not exceeding Rs. 25 crore in any preceding financial year, working towards innovation, development, deployment or commercialization of new products, process or services driven by technology or intellectual property. If we talk about the formal definition of start-up in Indian context, then a clear definition of it does not exist but the Department of Industrial Policy and Promotion (DIPP) is working on giving a clear definition for the start-ups.

The Prime Minister, in his Independence Day speech in the year 2015 announced the "Start-up India" initiative and formally launched it on January 16, 2016. This initiative aims at promoting innovation along with fostering entrepreneurship and thereby creating an ecosystem that is conducive for growth of start-ups. This initiative is aimed to go a significant way in reiterating the Government of India's commitment for making India the hub of innovation, design and Start-ups. Start-ups traditionally have 
been local enterprises run by small business entrepreneurs. Today, with Internet's global reach, entrepreneurs have the ability to tap networks and establish start-up operations all across the world.

\subsection{Objectives of the Study}

The specific objectives of the paper are as follows:

a) To study the Indian experience of start-ups and analysing the current position of it.

b) To analyse the challenges face by the start-ups in India in terms of financial resources.

c) To examine the ultimate fate of innovative start-ups.

\subsection{Review of Literature}

Goyal \& Parkash (2011) have shown that the position of entrepreneur presently is better than before. Economies are taking more pain to enhance the entrepreneurship and Government is also support for the same. In contrast to this, Sharifi \& Hossain (2015) examined the various financial challenges faced by start-ups in India. They also found that the start-ups face a lot of difficulties in the initial phase of its lifecycle in terms of setting up the business. In line with this, Damodaran (2009) also investigated and found in his study that there can be no denying the fact that young companies pose the most difficult estimation challenges in valuation.

According to Ensley, Hmieleski and Pearce (2006) the descriptive value of shared leadership goes over the vertical leadership. This suggests that the high profile cases of reckless start-ups, whose creativity and innovation has led to the renowned empires, are more folk tale than reality. In relation to the social and human capital Bosma, Praag, Thurik \& Wit (2002) presented a detailed study of firms investing in the human and social capital for improving the performance. Caliendo, Hogenacker, Kunn\&Wiebner (2015) examined and found the difference between subsidized start-ups out of unemployment and non-subsidized start-ups out of non-employment. Kumar (2015) examined and found that Indian start-up scenario has come a long way with the growth in information technology and the entry of accelerators and incubators has played a crucial role in shaping the path of these start-ups.

Sharma (2013) pointed out through the study on women entrepreneurs in India that women entrepreneurs face many problems like social, legal, education and family support like barriers. Sarkar (2016),inspected how the entrepreneurs provide energy for the economics to grow and how the growth of an economy is also influenced by the number of young ideas and start-up. Bernstein, Korteweg \& Laws (2015) did a field 
experiment and found that the investors react most strongly to information about the start-up's founding team.

\subsection{The Indian Start-up Ecosystem}

The different elements of a start-up ecosystem have been listed in Table 1. A start-up ecosystem is mainly formed by people, start-ups in their different stages and different types of organizations in a location, interacting as a system to create the new start-up companies (Figure 1).

\section{Table1: Elements of Start-up ecosystem}

\begin{tabular}{|c|c|}
\hline Elements of Startup ecosystem & $\begin{array}{l}\text { Organizations and activities with start- } \\
\text { up activities }\end{array}$ \\
\hline $\begin{array}{ll}\text { - } & \text { Ideas, inventions and researches } \\
\text { - } & \text { Start-ups at various stages } \\
\text { - } & \text { Entrepreneurs } \\
\text { - } & \text { Start-up team members } \\
\text { - } & \text { Angel investors } \\
\text { - } & \text { Start-up mentors } \\
\text { - } & \text { Start-up advisors } \\
\text { - } & \text { Other entrepreneurial minded } \\
\text { - } & \text { people } \\
& \text { Third people from other } \\
& \text { organizations with start-up } \\
& \text { activities }\end{array}$ & $\begin{array}{ll}\text { - } & \text { Universities } \\
\text { - } & \text { Advisory \& mentoring } \\
\text { - } & \text { organizations } \\
\text { - } & \text { Startup incubators } \\
\text { - } & \text { Co-working spaces } \\
\text { - } & \text { Service providers (consulting, } \\
\text { - } & \text { accounting, legal, etc.) } \\
\text { - } & \text { Start-up competitions } \\
\text { - } & \text { Investor networks } \\
\text { - } & \text { Venture capital companies } \\
\text { - } & \text { Crowd funding portals } \\
\text { - } & \text { Other funding providers (loans, } \\
& \text { grants etc.) } \\
\text { - } & \text { Start-up blogs \& other business } \\
& \text { media } \\
\text { - } & \text { Other facilitators }\end{array}$ \\
\hline
\end{tabular}

\subsection{The start-up lifecycle stages}

The start-up lifecycle stages can be defined in the below mentioned manner ${ }^{2}$ :

a) Problem/Solution Fit: This stage give stress on first of all identifying the problem which exist in the environment and then going for finding the solution by discovering or identifying the scalable product/service idea for a potential market. 
b) Minimum Viable Product (MVP): This is the validation of the idea and to validate the product idea we should test it with the smallest possible investment of time and capital, hence, minimum viable product.



Figure 1: Start-up Ecosystem

c) Product/Market Fit: In order to establish the product we should follow the language market fit approach, funnel optimization and channel/ product fit approach.

Language/Market Fit- In the process of establishing the product, the key is to figure out how to talk to the users about what your product actually does so that they "get" it.

Funnel Optimization - Funnel optimization is basically a process where the different experience of the users are noted so that the points of confusions could be reduced and ultimately removed.

Channel/Product Fit - This step is to figure out a process of channel discovery which will not only be efficient but also viable for reaching to the target customers. 
d) Scale: According to Morgan Brown ${ }^{3}$, by the time a product/service reaches this stage, the entrepreneur has an idea of some channels that work, if the start-up person is confident enough about the revenue conversion flows and retention rates, so it's finally the time to pour it on.

e) Maturity: The growth rate of a start-up may slow down as it matures, in this stage new measurements could be taken to improve revenue like innovating the existing product.

\subsection{Start-up Funding Process}

The start-up funding process has various aspects which change with respect to change in time. These are explained below:

a) Funding by Angel investors/Seed funds: The early stage of start-ups basically depend upon the angel investors and seed funding. They generally invest in the new start-up entrepreneur with an innovative idea but do not want any kind of corporate governance formalities.

b) Venture Capital: These sources of finance provide money to start-ups when they at the growth stage. They basically scale the company's business model.

c) Public Markets: The start-ups who are in the expansion stage, gets the funds from the public markets in order to increase the capacity of the company manifold.

\subsection{Start-up Funding in India}

In India, the start-ups are being funded either by the own capital of the start-up owners or with the help of Seed Funding, Series A, Series B, and Series C funds for the start-ups during its life cycle.

\subsubsection{Funding Based on Life Cycle of a Start-up}

a) Seed Funding

Seed funding is like planting a seed for a tree. This round nurtures the seed idea. It is made in order to support the market research and development work for the company so that the start-up team could launch the product for the target audience. The seed funding provides capital from $\$ 500,000$ to $\$ 2$ million.

b) Series A Round

After the start-up show a positive sign of revenue generation and a good track record, series A funding is useful in order to optimize the product and its user base. In order to make this start-up into a developing business model, this round provides capital from $\$ 2$ million to $\$ 15$ million.

c) Series B Round

In this round, the businesses are taken into the next level like increasing the competitiveness, market reach etc. In Series B, the venture capitalists have more vision 
about the shape of the pie and the size of the slice they hope to have in future. Here, the capital raised fluctuates from $\$ 7$ million to $\$ 10$ million.

\section{d) Series $C$ Round}

The Series $\mathrm{C}$ rounds inject more capital in the start-up for boosting the successfulness of the businesses in the hope of getting more than $100 \%$ returns. This funding is generally made to scale up the business in terms of expanding production and acquiring another company too.

\subsubsection{Funding Based on Age of a Start-up}

The funding for a start-up is based on the age of the start-up. The start-ups can be categorized into two different stages viz; early stage and growth stage.

a) Early Stage:

- 1 Year - Start-ups may get the funds from the family and friends.

- 3 Years- Start-ups in the age of 3 years or less but more than 1 year may get the funds from the Angel investors/Seed funds.

b) Growth Stage:

- 5 Years - Start-ups in the age of 5 years or less but more than 3 years may get the funds from the Venture capitalist or private equity or banks.

- 8 Years - Start-ups in the age of 8 years or less but more than 5 years may get the funds from the Public market with the help of IPOs.

\subsection{Assistance provided by the Government to Start-ups}

a) MUDRA Bank: For the purpose of financial assistance, the finance minister himself, in his Union Budget speech for 2015-16, announced that the government's is planning to set up Micro Units Development Refinance Agency (MUDRA) Bank and a Credit Guarantee Fund with a refinance capital of INR 20,000 crore and INR 3,000 crore.

b) India Aspiration Fund: Finance minister also announced the 'India Aspiration Fund' in order to encourage the start-up ecosystem and allocated Rs.400 crore to various venture funds. Another program called SMILE (SIDBI Make in India Loan for Small Enterprises) was launched with an allocation of Rs. 10,000 crore.

c) Start-up Exchange: The SEBI is also planning to make all new set of listing norms for start-ups, including the e-Commerce ventures in order to raise funds from listing on exchange.

d) Self-Employment and Talent Utilisation (SETU): The government also planned to set up a mechanism known as SETU, under the headship of newly formed NITI Aayog, to 
provide the technical assistance and also incubation to start-ups. In 2015 Union Budget has set aside Rs. 1,000 crore for supporting the start-ups.

\subsection{India's Present Start-up Picture}

According to NASSCOM report 2015, India ranks third among global start-up ecosystems with more than 4,200 new-age companies and India is amongst the top five countries in the world in terms of the new business start-ups.

\subsection{The Indian Start-up Industry Composition}

The total number of start-ups in India till now is approx. 10,000 including 4,300 technology based and 5,700 non-technology based start-ups. Although non-technology base has 57\% share and technology base are covering $43 \%$ but that means the technology is also fostering and as per recent, there are on an average 800 new technology based start-ups that have opened in India (Figure 2).

\subsection{Current State of Indian Start-ups}

India is the $3^{\text {rd }}$ largest start-up hub and the average age of the founders in India for start-up is 28 years out of that $9 \%$ of the total start-up entrepreneurs are women ${ }^{4}$. It is also interesting to know that in the last 12 months the contribution of female entrepreneur in start-ups was $50 \%$. The average numbers of new technology based startups were 480 in 2010 which crossed the mark of 800 in 2015. It is also expected to increase to the level of 2,000 by the end of 2020.The number of incubators in India has grown by $40 \%$ to 110 during the financial year 2014-15 and the majority of start-up investors were from the metro cities. With the help of these start-ups, the SMEs created approx. 60\% new jobs during the period of 1993-2013.According to World Bank's report published in 2015 in terms of 'ease of doing business' on the basis of 11 defined parameters which are based on the data of two cities i.e. Delhi \& Mumbai, India's ranking according to that parameters is given in Table 2 . 


\section{Technology Based Startups}

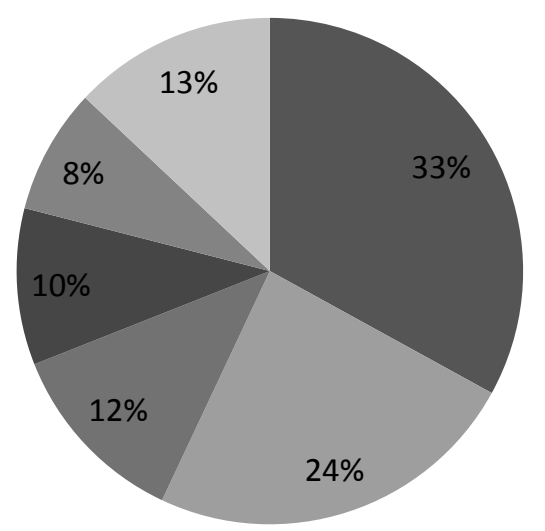

E-commerce

B2B -

- Consumer internet

Mobile apps -

- Software-as-a-Service (SaaS)

Other

\section{Non-Technology Based Startups}

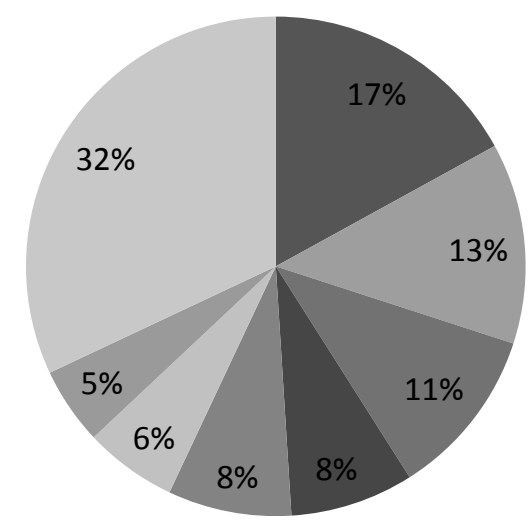

Engineering

Construction

Agri products

- Textile

Printing \& packaging

Transport \& logistics

- Outsourcing \& support

Other

Figure 2: Sectoral Concentration of Start-ups 
42 | PRAGATI: Journal of Indian Economy, Volume 3, Issue 2

Table 2: India's position on Ease of Doing Business

\begin{tabular}{|l|c|c|c|}
\hline Topics & $\begin{array}{c}\text { Rank in 2016 } \\
\text { (out of 189) }\end{array}$ & $\begin{array}{c}\text { Rank in 2015 } \\
\text { (out of 189) }\end{array}$ & $\begin{array}{c}\text { Change in } \\
\text { Rank }\end{array}$ \\
\hline Starting a Business & 155 & 164 & +9 \\
\hline $\begin{array}{l}\text { Dealing with Construction } \\
\text { Permits }\end{array}$ & 183 & 184 & +1 \\
\hline Getting Electricity & 70 & 99 & +29 \\
\hline Registering Property & 138 & 138 & No change \\
\hline Getting Credit & 42 & 36 & -6 \\
\hline $\begin{array}{l}\text { Protecting Minority } \\
\text { Investors }\end{array}$ & 8 & 8 & No change \\
\hline Paying Taxes & 157 & 156 & -1 \\
\hline Trading Across Borders & 133 & 133 & No change \\
\hline Enforcing Contracts & 178 & 178 & No change \\
\hline Resolving Insolvency & 136 & 136 & No change \\
\hline
\end{tabular}

Source: http://www.doingbusiness.org/data/exploreeconomies/india/

\subsection{A Comparison of India's Start-ups with other countries}

It can be seen from Table 3 that the contribution of technical and non-technical based start-ups are further pumping the growth of the start-ups in India and non-technical based start-ups are more than the technical start-ups.

Table 3: Comparison of India Start-ups

\begin{tabular}{|c|c|c|c|c|c|c|}
\hline & India & China & Israel & Singapore & Japan & $\mathbf{U S}$ \\
\hline Total no. of start-ups & 10,000 & 10,000 & 4,750 & N.A. & N.A. & 83,000 \\
\hline Tech-based start-ups & 4,300 & 3,400 & 4,000 & N.A. & N.A. & 48,500 \\
\hline Non-tech based start-ups & 5,700 & 6,600 & 750 & N.A. & N.A. & 34,500 \\
\hline $\begin{array}{l}\text { Set up a new business } \\
\text { (Days) }\end{array}$ & $30-60$ & 30 & 13 & 2 & 10 & 4 \\
\hline Corporate tax rate & $34 \%$ & $25 \%$ & $26 \%$ & $\begin{array}{l}17 \%(100 \% \\
\text { tax exemption } \\
\text { for start-ups) }\end{array}$ & $34 \%$ & $39 \%$ \\
\hline $\begin{array}{l}\text { No. of Tax payments by } \\
\text { businesses (p.a.) }\end{array}$ & 33 & 9 & TBD & TBD & TBD & 11 \\
\hline Bank lending rate & $10.3 \%$ & $5.6 \%$ & $3.9 \%$ & $5.4 \%$ & $1.2 \%$ & $3.3 \%$ \\
\hline $\begin{array}{l}\text { R\&D spending \% of } \\
\text { GDP }\end{array}$ & $0.85 \%$ & $1.90 \%$ & $\begin{array}{l}4.20 \\
\%\end{array}$ & N.A. & $3.40 \%$ & $2.80 \%$ \\
\hline
\end{tabular}

Source: World Bank Report, 2015. 


\subsection{Challenges in the Path of Starup}

According to the World Bank Report, 2016 there are some issues which India needs to resolve in order to promote an environment of entrepreneurship and start-ups.

- The tax rate which is to be paid even to a new start-up is between $30-33 \%$ which is a demotivating factor specially for a start-up whose revenue in the initial phase may not be able to cover even the cost of production. Although the present government has given tax relief for two years, however more incentives need be given to startups.

- The start-up enterprise has weak credibility in the initial phase of its life cycle and low credit performance. Therefore, this has resulted in low credit rating and more than half of the start-ups are going through the financial crisis. In some cases the start-ups try to evade the taxes which further damages their credit standing.

- In comparison with large organisations, these small start-ups have poor ability to resist risk. Further, they lack enough funding for production, improving research and development ability, improving product quality and competitiveness.

- The smaller start-ups may not be able to get funds from the Angel investors or from the Seed funding institutions if they do not have a brilliant idea to share. This is because these institutions give the funding to start-ups only when they are sure that the idea will be successful and they will be able to exit from this venture with more than $200 \%$ returns, which may not be possible in each and every start-up.

\subsection{Analysis of Post Start-Up Scenario of Selected Companies}

The present paper has analysed the post start-up scenario in the context of acquisition of some selected start-ups being acquired by the global companies. For this purpose, the researcher has selected the following start-up acquisitions that took place in the year 2014 and 2015 (Table 4).

\section{The Post-Acquisition Scenario}

\subsection{Brand Image}

In the context of the brand image, after acquiring the unique start-ups by the global companies, their presence is now more being felt in the industry in which they operate. Not only that, some of them have gained a very crucial position in terms of creating a good market reputation in the eyes of their existing and prospective customers. This phenomenon is applicable in all the selected companies whether it is Yahoo, 
44 | PRAGATI: Journal of Indian Economy, Volume 3, Issue 2

FoodPanda, News Corp, Twitter or Practo. Even in the case of Ola, it has become a more reputative brand in the cab industry and more number of customers are preferring it. Same is the case with Capillary Technologies which can now handle 500 million transactions a year and this expanded capacity has result in the increase in its market reputation.mGage's customer are fortune 1000 companies across the globe, so its acquisition improved the brand image of Unicel.

Table 4: Details of acquisition of some selected start-ups

\begin{tabular}{|c|c|c|c|c|c|}
\hline $\begin{array}{l}\text { S. } \\
\text { No }\end{array}$ & Product/Industry & Start-up & $\begin{array}{l}\text { Acquired } \\
\text { by }\end{array}$ & $\begin{array}{c}\text { Year of } \\
\text { Acquisition }\end{array}$ & $\begin{array}{l}\text { Purchase } \\
\text { Considerati } \\
\text { on (Value) }\end{array}$ \\
\hline 1 & Document Viewing Tool & BookPad & Yahoo & 2014 & $\$ 15$ million \\
\hline 2 & $\begin{array}{l}\text { Social Media Consulting } \\
\text { and } \\
\text { Messaging/Communications }\end{array}$ & Cooltok & Kirusa & 2014 & $\$ 10$ million \\
\hline 3 & Online food Ordering & TastyKhana & FoodPanda & 2014 & $\$ 25$ million \\
\hline 4 & Android Apps developer & Little Eye Labs & Facebook & 2014 & $\$ 15$ million \\
\hline 5 & Financial advisory Service & BigDecisions.com & News Corp & 2014 & $\begin{array}{l}\text { \$25 million } \\
\text { (Estimated/ } \\
\text { Not } \\
\text { disclosed) }\end{array}$ \\
\hline 6 & Cab service & Taxi For Sure & Ola & 2015 & $\begin{array}{l}\$ 200 \\
\text { million }\end{array}$ \\
\hline 7 & $\begin{array}{l}\text { Integrated Cloud } \\
\text { Communications Solutions } \\
\text { (across SMS, Voice, USSD, } \\
\text { and Email) }\end{array}$ & Unicel & mGage & 2015 & $\$ 15$ million \\
\hline 8 & Mobile marketing platform & Zipdial & Twitter & 2015 & $\$ 35$ million \\
\hline 9 & $\begin{array}{l}\text { Cloud based hospital } \\
\text { management systems and } \\
\text { electronic medical records } \\
\text { software solutions }\end{array}$ & InstaHealth & Practo & 2015 & $\$ 12$ million \\
\hline 10 & $\begin{array}{l}\text { Digital commerce solution } \\
\text { (Amplifying the business } \\
\text { prospects of retailers) }\end{array}$ & MartJack & $\begin{array}{l}\text { Capillary } \\
\text { Technologie } \\
\text { s }\end{array}$ & 2015 & $\begin{array}{l}\$ 14.5 \\
\text { million } \\
\text { (Estimated/ } \\
\text { Not } \\
\text { disclosed) }\end{array}$ \\
\hline
\end{tabular}

\subsection{Market Share}

The market share of the companies who acquired the start-ups has significantly increased that too in just one year period. After acquiring BookPad, Yahoo has changed 
its e-mail interface and strengthen Yahoo mail. It is result of the start-up acquisition that the Indian taxi market has become more competitive with the increase in the operating capacity of Ola after acquiring Taxi For Sure. Even as per some source, Ola Cabs are now generating close to $\$ 12$ million every month by capturing the $55 \%$ of the market share. Similarly Practo has added more than 1,00,000 new customers after acquiring InstaHealth. So is the case with $m$ Gage whose revenue has increased from $\$ 90$ million to $\$ 100$ million, FoodPanda having 20\% growth in every quarter in revenue and Capillary Technologies can now handle 500 million transactions a year and every transaction is equal to revenue for it.

\subsection{Quality Improvement}

The quality improvement is a dimension which is observed in each and every case. If we talk about the News Corp, after acquisition of BigDecisions.com, it now provides more qualitative financial service to its customers. Ola has reduced the waiting time of customers to 3-5 minutes which earlier was around 10-15 minutes for every customer. Kirusa can now deliver more social media messaging/communications. FoodPanda now process the order faster than the earlier, it now even give 45 minutes delivery promise or money back guarantee. via ZipDial, the Twitter now got access to those who even have an erratic Internet access. Practo has created a more wide platform for the platform its customers by giving access to patients the option to search and find information about availability doctors and instant bookings. It now provides the patients to access their health records post discharge on web or on the mobile app. The Capillary, after buying MartJack, personalized the customer engagement through an omni-channel strategy which resulted in not only increase in the customers but also improved the quality of its service. Similarly, after the combined organization, $m$ Gage now can handle more than 60 billion transactions annually which resulted in expanded multi-channel mobile engagement platform.

\subsection{Employment Opportunity}

When there is increase in the operation capacity as well as number of customer, this led to increase in the number of employees too for an organization. The same has happened with these global companies when they acquired the start-ups. The Ola has created an employee base of more than 8000 (includes Ola cab drivers) out of which more than 1000 has been added in the last one year. Kirusa has 1000 employees which includes 100 new employees added. Similarly, on an average there has been more than $10 \%$ of employment generation by the global companies after they acquired the start-ups 
due to increase in the operating activities and demand of their product/service except Yahoo, who reported a $15 \%$ lay off of workers, but this was due to some other factors.

\subsection{Conclusion}

India is the $7^{\text {th }}$ largest country by the area size and also the $2^{\text {nd }}$ most populous country accommodating people over 1.2 billion. Besides this, the large population implies large potential market in India; but, it also leads to the heavy employment pressure in Indian economy. In the last couple of years, the self-employment consciousness among the employment seeking persons has been increased specially in youngsters. Many initiatives have been taken by the current government in order to promote the environment of entrepreneurship and give incentives to young start-ups by providing the new and innovative schemes which would not only provide the funds to these start-ups but also the helping these starts up in setting the business with the help of information technology. There are many opportunities have been created by the government in terms of MUDRA bank, SMILE, Start-up Exchange, India Aspiration Fund, Self-utilisation and Talent Utilisation (SETU)etc. Since these institutions are either being built or in the process of making it usable but still it is very early and we can't say that whether this will create a window of new opportunities or its fate will be similar to other government schemes.

The analysis of post start-up scenario of some selected companies highlights that that new start-ups are opened in order to address a problem which exists in the society or to give a better product/service which may cater to the needs of the general public. However, when these start-ups get the grip on the market, they are normally acquired by global companies. When global companies acquire these start-ups, they do not change the synergy and basic theme of the start-up, as this is what they paid for. Moreover, these young start-ups are being funded by either Angel investors or private equity or venture capitalist and they are self-motivated. They invest only on those ventures that are worth investing and which will give at least 2-3 times boost to their investment.

\section{Endnotes}

1. Peter Drucker (1985) quoted the Economist in his book "Innovation and Entrepreneurship": "Over 600,000 new businesses are started in the US every year. This number is seven times the equivalent figure during the prosperity 1950's and 60's. America's new businesses create a large share of new employment opportunities." 
2. http://growthmarketingconf.com/5-phases-of-the-startup-lifecycle-morgan-brown-on-whatit-takes-to-grow-a-startup/

3. Morgan Brown is Growth Driven Chief Operating Officer, works with early stage companies on an interim basis to help them gain traction and reach their milestones through user acquisition, user retention and revenue growth, in Orange County-området, Californien, USA.

4. NASSCOM Startup India report 2015, Startup India-Momentous Rise of the Indian Startup Ecosystem, CII report on a snapshot of India's Startup Ecosystem, Secondary sources, News article

\section{References}

ASSOCHAM \& Grant Thornton. (2016). Start-ups India - An Overview. New Delhi.

Bernstein, S., Korteweg, A.G., \& Laws, K. (2015). Attracting Early Stage Investors: Evidence from a Randomized Field Experiment. Social Science Research Network $(S S R N)$, p.1-47. Retrieved from: https://papers.ssrn.com/sol3/papers.cfm?abstract_id=2432044

Bosma,N., Praag, M. V., Thurik, R., \& Wit, G. D. (2002). The value of human and social capital investment for the business performance of start-ups. Tinbegren Institute Discussion Paper,2002-027/3. Retrieved from: http://papers.tinbergen.nl/02027.pdf

Caliendo, M., Hogenacker, J., Kunn, S., \&Wiebner, F. (2002). Subsidized start-ups out of unmployment : A comparison of regular business start-ups. IZA Discussion Paper Series,8817. Retrieved from: http://ftp.iza.org/dp8817.pdf

Damodaran, A. (2009). Valuing Young, Start-up and Growth Companies: Estimation Issuesand Valuation Challenges. Social Science Research Network (SSRN), p.1-67. Retrieved from: https://papers.ssrn.com/sol3/papers.cfm?abstract_id=1418687

Drucker, P.F.(1985). Innovation and Entrepreneurship ( $1^{\text {st } e d .) . ~ N e w ~ Y o r k: ~ C o l l i n s ~}$

Ensley, M.D., Hmieleski, K. M., \& Pearce, C. L. (2006). The importance of vertical and shared leadership within new venture top management teams: Implication for the performance of the start-ups. The Leadership Quarterly, 17(3),217-231. 
48 | PRAGATI: Journal of Indian Economy, Volume 3, Issue 2

Goyal, M., \&Prakash, J. (2011). Women entrepreneurship in India-problems and prospects. International Journal of Multidisciplinary Research, 1(5),195-207.

Kumar, K. (2015). Indian Online Start-ups: Can they Stand Up Against the World. International Journal of Advance Research in Computer Science and management Studies, 3(4), 236-243.

NASSCOM. (2015). Start-up India: Momentous Rise of the Indian Start-up Ecosystem. New Delhi: International Youth Centre.

Sarkar, A. (2016). Start-up India - A New Paradigm for Young Entrepreneurs (A Conceptual Study). Social Science Research Network (SSRN), p.1-9. Retrieved from: https://papers.ssrn.com/sol3/papers.cfm?abstract_id=2835322

Sharifi, O., \& Hossein, B. K. (2015). Understanding the Financial Challenges Faced by Start-ups in India. International Journal of Science, Technology and Management,4(1), 264-272.

Start-up India Action Plan. (2016). January.

Sharma, Y.. (2013). Women entrepreneur in India, IOSR Journal of Business Management, 15(3), 09-14. Retrieved from: http://www.iosrjournals.org/iosrjbm/papers/Vol15-issue3/C01530914.pdf. 